\title{
The Effect of Fertigation with Nano NPK Fertilizers on Some Parameters of Growth and yield of potato (Solanum tuberosum L.)
}

\author{
Hayyawi W.A.Al- juthery ${ }^{1}$,Qusay.M.N.Al-Shami ${ }^{1 *}$ \\ ${ }^{1}$ (College of Agriculture / University of Al-Qadisiyah, Iraq) \\ E-mail: hayyawi.aljutheri@qu.edu.iq \\ E-mail: Qusay.murad1983@gmail.com
}

Received : 3/7/2019

Final Revision : 20/8/2019

\begin{abstract}
A field experimentt has been carried out in the Autumn season of 2017 in one of the fields of the College of Agriculture - University of Qadisiyah to determine the response of the potato (Solanum tuberosum L.) to the fertigation with nano fertilizers of macro elements NPK on the growth and yield of the potato cultivar Arizona under drip irrigation system. The experiment has included 9 treatments of fertigation single Nano $\mathbf{N}, \mathbf{P}, \mathrm{K}$, di combination nano $(\mathrm{N}+\mathrm{P}),(\mathrm{N}+\mathrm{K}),(\mathbf{P}+\mathrm{K})$, tri nano $(\mathrm{N}+\mathrm{P}+\mathrm{K})$ and conventional fertilizers (NPK20:20:20) In addition to the comparative treatment, according to design of RCBD and one way simple treatment with 4 replicates .

Fertilizers have been injected with levels of addition of $40 \mathrm{~L} \mathrm{~h}^{-1}$ of nano nitrogen fertilizer $25 \% \mathrm{~N}, 10 \mathrm{~kg} \mathrm{~h}$ 1 of nano phosphorus fertilizer $25 \% \mathrm{P}$ and $20 \mathrm{~kg} \mathrm{~h}^{-1}$ of nano potassium fertilizer $35 \% \mathrm{~K}$ and $300 \mathrm{~kg} \mathrm{~h}^{-1}$ traditional fertilizer Tron (NPK 20:20:20) ) in four batches 10\%, 20\%, 30\% and 40\% of the quantities of fertilizers added to the first, second, third and fourth batches respectively. The growth parameters tested are plant height, chlorophyll content in leaves, vegetative dry matter yield, soft tubers yield, biological yield, dry tubers yield, starch, protein , The results of the Duncan test under a significant level of 0.05 showe that the following fertigation of nano $(\mathrm{N}+\mathrm{P}+\mathrm{K})$ give has given the highest rate of vegetative qualities and the quality of all yield and significantly exceeded the di combinations and individual fertigation in some traits (plant height and chlorophyll content SPAD.higher nano $(\mathrm{N}+\mathrm{P}+\mathrm{K})$ combination in the vegetative yield, the soft tubers yield, the biological yield, dry matter yield of tubers, the total yield protein and starch $(2.148,48.221$, 11.395, 9.246,843. 871 and 6.355 $\mathrm{Mg} \mathrm{h}^{-1}$ ) .
\end{abstract}

Key words: Nano NPK, Fertigation, Potato, Protein, Starch.

*The research is part of MSc for $2^{\text {st }}$ author

\section{INTRODUCTION}

Agriculture workers face many challenges such as declining crop productivity and low efficiency of fertilizer use (FUE) due to low soil organic matter, nutrient depletion, climate change, declining arable land and low availability of water. However, we need to achieve sustainable growth in agriculture. At least $4 \%$ to meet food security challenges. To address some of these challenges, it is necessary to apply leading technologies such as nanotechnology to accurately detect how to provide the right amount of nutrients that enhance productivity while ensuring environmental safety and high nutrient efficiency (Subramanian et.al., 2007) So that nano- slow controlled fertilizers can be used as environmental and friendly to achieve sustainable, environment-friendly agriculture that operates with nanomaterials $(1-100 \mathrm{~nm})$ specifically for that have some characteristics that differ from those in their volumetric diameter (Naderi, Danesh, 2013, and safavi, 2016).

Nanofertilizers are more effective and efficient than traditional fertilizers because of their positive effects on the quality nutrition of crops and the reduction of stresses in plants and the lack of added quantities and costs for their rapid uptake by the roots and their penetration into cells and transport and representation within the plant tissues (Morales-Diaz et .al., 2017, Singh, 2017, Ali and Al -juthery, 2017).

Fertigation is one of the fertilizer application methods in which fertilizer is combined with irrigation water by modern sprinkler and drip irrigation systems. After dissolving the nutrient fertilizers in solution and injected with irrigation water that provides nutrients and water. Essential elements are then directly available to the active root zone, thus reducing nutrient fertilizers and increasing their efficiency to $60 \%$, which ultimately helps to improve 
the yield and quality. Fertilizer use efficiency is increased from 80 to 90 per cent (Rachna Rana et .al., 2014). Shedeed et. al. (2009) have pointed out that adding certain nutrient concentrations with irrigation water improves the consistent distribution of nutrients and improves the fertilizer use efficiency, as well as reducing nitrogen washing in the form of nitrate $\left(\mathrm{NO}_{3}{ }^{-1}\right)$ and potassium to the root zone. Phosphorus at any level is more readily available relative to terrestrial addition. This is an efficient method of adding fertilizer (Segares, 2002, Fares and Abaas, 2009).

This technique provides the right mineral nutrition allowing for increased nutrient efficiency. However, nutrient determinants when harvest is needed and adapted to its water needs are essential for accurate plant nutrition and high nutrient efficiency as a successful method of reducing pollution (Bres, 2009, and Al-Jutheri, 2011).Potato (Solanum tuberosum L.) is one of the most important strategic food crops in the world and is ranked the fourth after wheat, rice and maize in terms of human consumption (Karam et. al., 2009, Kandil et. al., 2011). With an average annual consumption of $50 \mathrm{~kg}$ per capita in the period 2010-2015 (Scl, 2015) because it is rich with protein carbohydrates, vitamins, nutrients, simple sugars (FAO, 2013, Banjare et. al., 2014). Potato is also a highconsumption crop of fertilizers due to its absorption of nutrients to its root density and shortening its growth and high production of tubers (Al-Sahaf, 1994). Potato can absorb high amounts of special nutrients "NPK from the soil during the growing period to obtain high yields of tubers and good quality (White et. al., 2007). Therefore, the current study aims at studying the role with fertigation single ,di and tri with nano NPK fertilizers on potato growth , yield and quality of yield in comparison with to traditional fertilizer.

\section{Materials and Methods}

A field experiment has been conducted in one of the fields of the department Horticulture and Garden Engineering of collge of Agriculture - University of Al-Qadisiyah ,in a sandy loam soil with the properties shown in table 1., to the study of the effect of fertigation with nano NPK fertilizers on some parameters of growth and yield of potato (Solanum tuberosum L.). The experiment has included nine compatibility treatments for the fertigation of $\mathrm{N}, \mathrm{P}$ and $\mathrm{K}$ nano fertilizers and their different combinations are has been added in four unequal increments to match the growth stages of the crop by the amount of fertilizer, the number of injection times and the mixing ratios on shown in Table 2.

In a simple experiment using RCBD and four replicates. It begin on 20/9/2017, potato tubers are have been planted Arizona cultivar after sterilization $300 \mathrm{ml}$ of $\mathrm{K}$ are ptanol of Spain origin per $100 \mathrm{~L}^{-}{ }^{1}$ of water through immersion for 15 minutes to get rid of fungal and bacteria diseases and $0.2 \mathrm{~m}$ between tuber and others, from the top of the furrow and along the line. Irrigation is they been done using a dripping irrigation system prepared for this purpose and through operated with a consistency coefficient of $94.33 \%$, Fertilizers is has been added by the fertilization process by dissolving the required amount of fertilizer in each addition in plastic suspension bottles prepared for this purpose with a diameter of $0.15 \mathrm{~m}$ and a size of 6 liters and contain a valve to control the descent of the mixture fertilizer for each transaction and 2 valve at the ends. The treatment line $3 \mathrm{~m}$ contains 15 emitters to ensure no leakage between the treatments.

The process of injecting of the mixture after 5 minutes from the starting of the irrigation process then closing the valves between the treatments and the opening the valves of the bottles to allow the mixture of fertilizer into the emitters and after the completion of fertigation process an equivalent amount of water 6 liters is added to wash the bottles and falling pipes and then opening the valves to complete irrigation process and according to water consumption for that day. After the plant has reached its maturity, the tubers are have been harvested on the 15 January 2018 after harvesting the vegetative parts. All growth and plant growth effects are have been taken from plants in the central quartile from each experimental unit.

At the stage of tubers maturity some parameters of growth and yield are have been estimated. Soil analyses are conducted before the trial by using methods mentioned in (Table 1) for physical and chemical soil properties. Total chlorophyll in the youngest expanded leaves is has been recorded by SPAD (chlorophyll content) readings with a SPAD-502 Chlorophyll Meter (Minolta Camera Co. Ltd., Japan)..yield dry matter of vegetative is has been estimated for 10 plants and dry mater of tubers yield $\mathrm{Mg} \mathrm{ha}^{-1}$ are have been measured according to (A.O.A.C, 2000). Total dry matter content was determined by oven drying at 70.C for $24 \mathrm{~h}$. The amount of starch w is has been determined by using the equation $\%$ of starch in tubers $=17.55+0.89$ ( $\%$ of dry matter in tubers -24.18$)$. 
Table1.Some Soil Properties

\begin{tabular}{|c|c|c|}
\hline Property & Value & Estimated Methods \\
\hline \multicolumn{3}{|c|}{ Particle Size Distribution ( $\mathrm{gm} \mathrm{kg}^{-1}$ soil) } \\
\hline Clay & 379.2 & \\
\hline Silt & 436.9 & \\
\hline Sand & 183.9 & \\
\hline Texture & Sand Loamy & Kilmer and Alexander ,1949 \\
\hline CEC $\mathrm{Cmol}_{\mathrm{c}} \mathrm{kg}^{-1}$ Soil & 22.5 & Salim and Ali,2017 \\
\hline $\mathrm{OM} \quad \mathrm{gm} \mathrm{kg}^{-1}$ Soil & 12.0 & Salim and Ali,2017 \\
\hline Calcite $\mathrm{gm} \mathrm{kg}^{-1}$ Soil & 177 & Salim and Ali,2017 \\
\hline $\mathrm{pH}$ & 7.5 & Salim and Ali,2017 \\
\hline $\operatorname{EC}(1: 1)\left(\mathrm{dS} \mathrm{m}^{-1}\right)$ & 2.1 & Salim and Ali,2017 \\
\hline \multicolumn{3}{|c|}{ Available Macronutrients ( $\mathrm{mg} \mathrm{kg}^{-1}$ soil) } \\
\hline $\mathrm{N}$ & 22 & Salim and Ali,2017 \\
\hline $\mathrm{P}$ & 15 & Salim and Ali,2017 \\
\hline $\mathrm{K}$ & 177 & Landon, 1984 \\
\hline Bulk Density $\mathrm{Mg} \mathrm{m}^{-3}$ & 1.37 & Landon, 1984 \\
\hline
\end{tabular}

Table2.Shows the Experiment Treatments, Quantities of Fertilizers and Number of Injections

\begin{tabular}{|c|c|c|c|c|c|}
\hline Tr.No & Treatments of spraying & $\begin{array}{c}10 \% \text { of } \\
\text { Fertilizer }\end{array}$ & $\begin{array}{c}20 \% \text { of } \\
\text { Fertilizer }\end{array}$ & $\begin{array}{c}30 \% \text { of } \\
\text { Fertilizer }\end{array}$ & $\begin{array}{c}40 \% \text { of } \\
\text { Fertilizer }\end{array}$ \\
\hline T1 & Control & 0 & 0 & 0 & 0 \\
\hline T2 & Nano Nitrogen*25\%N & 4 & 8 & 12 & 16 \\
\hline T3 & Nano phosphorus**25\%P & 1 & 2 & 3 & 4 \\
\hline T4 & Nano Potassium***35\%K & 2 & 4 & 6 & 8 \\
\hline T5 & Nano( N+P) & $1+4$ & $2+8$ & $3+12$ & $4+16$ \\
\hline T6 & Nano (N+K) & $2+4$ & $4+8$ & $6+12$ & $8+16$ \\
\hline T7 & Nano (P+K) & $2+1$ & $4+2$ & $6+3$ & $8+4$ \\
\hline T8 & Nano (N+P+K) & $2+1+4$ & $4+2+8$ & $6+3+12$ & $8+4+16$ \\
\hline T9 & Traditional $(20: 20: 20 N P K) * * *$ & 30 & 60 & 90 & 120 \\
\hline
\end{tabular}

40 Liter of Nano Nitrogen fertilizer ha ${ }^{-1} * * 10 \mathrm{Kg}$ Nano Phosphorus fertilizer ha ${ }^{-1} * * * 20$ Liter of Nano Potassium $\mathrm{ha}^{-1} * * * * 300 \mathrm{Kg}(20: 20: 20)$ traditional $\mathrm{ha}^{-1}$

Total nitrogen is has been determined by Kjeldal's method and multiplied by 6.25 to convert to crude protein according to A.O.A.C (2000). The total yield fresh tubers from each net treatment is has been weighed with the help of digital balance in $\mathrm{kg}$ per treatment and was converted into $\mathrm{Mg} \mathrm{ha}^{-1}$, yield dry of vegetative $\mathrm{Mg}^{-1}$ measured from five randomly taken plants at harvest and converted into $\mathrm{Mg} \mathrm{ha}^{-1}$,Water use efficiency (WUE) was calculated as the ratio of potato yield (Y) to total crop

Statistical analysis of collected data is has been performed by using Duncan's multiple range test (Al Sahuki and Whaib, 1990) of Genstat program. Statistical differences are have been considered significant at $\mathrm{p}<0.05$.

\section{Results}

The height of the plant: as Noted in the results of Table 3, All the treatments were significantly increased in the height of the plant and the highest increase is has been achieved when the fertigation of the combination of nano NPK fertilizers $(53.43 \mathrm{~cm})$ and the traditional fertilizer NPK of $(44.33 \mathrm{~cm})$ compared with the comparison treatment $(37.54 \mathrm{~cm})$ table 3 .

The results of Table 3. appear to be the result of the vegetative dry matter yield $\left(\mathrm{Mg} \mathrm{h}^{-1}\right)$. Fertigation of nano NPK fertilizers combination treatment results in a significant increase in yield of the vegetative dry matter $(2.148$ 
$\mathrm{Mg} \mathrm{h}^{-1}$ ) compared to the comparison treatment $\left(1.428 \mathrm{Mg} \mathrm{h}^{-1}\right)$ and thus significantly exceeded the treatment of the tri combination of the traditional source of fertilizers, which recorded yield of vegetative dry matter $\left(1.706 \mathrm{Mg} \mathrm{h}^{-1}\right)$

Table.3:Effect of fertigation Nano NPK fertilizers in vegetative qualities of potato

\begin{tabular}{|c|c|c|c|c|c|c|}
\hline $\begin{array}{c}\mathrm{Tr} . \\
\mathrm{N}^{\mathrm{O}}\end{array}$ & $\begin{array}{c}\text { Plant Height } \\
(\mathrm{cm})\end{array}$ & $\begin{array}{c}\text { Chlorophyll } \\
\text { SPAD }\end{array}$ & $\begin{array}{c}\text { Yield of } \\
\text { Vegetative dry } \\
\text { matter } \\
\mathrm{Mg} \mathrm{ha}^{-1}\end{array}$ & $\begin{array}{c}\text { Fresh tubers } \\
\text { Yield } \\
\text { Mg ha }^{-1}\end{array}$ & $\begin{array}{c}\text { Biological } \\
\text { Yield } \\
\text { Mg ha }^{-1}\end{array}$ & $\begin{array}{c}\text { Percentage of } \\
\text { Nitrogen in } \\
\text { Tuber\% }\end{array}$ \\
\hline $\mathrm{T}_{1}$ & $37.54 \mathrm{~d}$ & $37.00 \mathrm{e}$ & $1.428 \mathrm{f}$ & $30.666 \mathrm{~g}$ & $8.271 \mathrm{e}$ & $1.60 \mathrm{a}$ \\
\hline $\mathrm{T}_{2}$ & $45.04 \mathrm{bc}$ & $40.50 \mathrm{~cd}$ & $1.942 \mathrm{~b}$ & $42.444 \mathrm{~cd}$ & $10.062 \mathrm{~cd}$ & $1.607 \mathrm{a}$ \\
\hline $\mathrm{T}_{3}$ & $42.31 \mathrm{~cd}$ & $40.55 \mathrm{~cd}$ & $1.835 \mathrm{c}$ & $37.334 \mathrm{f}$ & $10.408 \mathrm{bc}$ & $1.472 \mathrm{~d}$ \\
\hline $\mathrm{T}_{4}$ & $41.11 \mathrm{~cd}$ & $39.08 \mathrm{de}$ & $1.648 \mathrm{e}$ & $39.334 \mathrm{ef}$ & $10.349 \mathrm{bcd}$ & $1.448 \mathrm{e}$ \\
\hline $\mathrm{T}_{5}$ & $50.73 \mathrm{ab}$ & $43.98 \mathrm{~b}$ & $1.987 \mathrm{~b}$ & $46.665 \mathrm{ab}$ & $10.643 \mathrm{~b}$ & $1.53 \mathrm{bc}$ \\
\hline $\mathrm{T}_{6}$ & $47.13 \mathrm{abc}$ & $42.10 \mathrm{bc}$ & $1.931 \mathrm{~b}$ & $44.664 \mathrm{bc}$ & $10.547 \mathrm{~b}$ & $1.540 \mathrm{~b}$ \\
\hline $\mathrm{T}_{7}$ & $46.06 \mathrm{bc}$ & $41.38 \mathrm{bcd}$ & $1.788 \mathrm{~cd}$ & $40.832 \mathrm{de}$ & $10.056 \mathrm{~cd}$ & $1.518 \mathrm{c}$ \\
\hline $\mathrm{T} 8$ & $53.43 \mathrm{a}$ & $47.45 \mathrm{a}$ & $2.148 \mathrm{a}$ & $48.221 \mathrm{a}$ & $11.395 \mathrm{a}$ & $1.460 \mathrm{de}$ \\
\hline $\mathrm{T} 9$ & $44.33 \mathrm{bc}$ & $42.35 \mathrm{bc}$ & $1.706 \mathrm{de}$ & $39.998 \mathrm{ef}$ & $10.006 \mathrm{~d}$ & $1.540 \mathrm{~b}$ \\
\hline
\end{tabular}

The results of Table (3) show that the highest fresh tuber yield is has achieved when the fertigation of tri nano NPK fertilizers $\left(48.221 \mathrm{Mg} \mathrm{h}^{-1}\right)$ is significantly higher on all treatments, including the tri for the conventional NPK fertilizer of $\left(39.998 \mathrm{Mg} \mathrm{h}^{-1}\right)$ and the comparison treatment $\left(30.666 \mathrm{Mg} \mathrm{h}^{-1}\right)$.

From the same table, it is noted that the Biological yield $\mathrm{Mg} \mathrm{h}^{-1}$ : The treatments of fertigation single,di,tri of nano fertilizers combination and conventional tri NPK complex fertilizer have a significant effect on the bilogical yield, achieving the highest rate of biological yied at the nano NPK synthesis of (11.395 $\left.\mathrm{Mgh}^{-1}\right)$ a compared with the comparison treatment $\left(8.271 \mathrm{Mg} \mathrm{h}^{-1}\right)$.

The percentage of dry matter in the tubers: Table (4) indicates that the coefficient of nano (P) $(22.96 \%)$ indicates is the highest percentage of dry matter in the tubers acompared with the comparison treatment $(22.31 \%)$.

Dry matter yield of tubers $\mathrm{Mg} \mathrm{h}^{-1}$ :Nano NPK fertilizers combination $\left(9,246 \mathrm{Mg} \mathrm{h}^{-1}\right)$ is has been found to be highest on compared with the comparison treatment. (6.843 $\mathrm{Mg} \mathrm{h}^{-1}$ ), thus exceeding the treatment of conventional fertilizers NPK $\left(8.300 \mathrm{Mg} \mathrm{h}^{-1}\right)$ table 4.

The percentage of protein in the tubers: It has been found that the treatments of the single,di, tri nano NPK fertilizers and the traditional source have is a significant effect on the percentage of protein in the tubers. The nano $\mathrm{N}(10.05 \%)$ has recorded the highest percentage of protein in the tubers acompared with comparison treatment $(10.00 \%)$ with no significant difference table 4.

Protein yield $\mathrm{kg} \mathrm{h}^{-1}$ : From the results of table (4), it is note that the treatments denonstrate that nano NPK combinations Single, bilateral and triple and conventional NPK have significantly increased protein yield. The highest yield is has been achieved in nano NPK , nano NP and nano NK of 843.871, 827.776 and $829.253 \mathrm{~kg} \mathrm{~h}^{-1}$ ) respectively, acompared with the control and conventional treatments $\left(684.020\right.$ and $\left.798.866 \mathrm{~kg} \mathrm{~h}^{-1}\right)$.

\%Starch in tubers: It is has been found that the treatment of nano $(\mathrm{P})$ alone has gotten higher Starch percentage (16.47\%) acompared with the comparison treatment (15.89\%) And their individual counterparts nano (N) and nano (P) It is generally observed that combination of nanoNPK unilateral, bilateral and trilateral and traditional source of NPK fertilizers(13.10 and 14.97\%) respectively have recorded the highest measurement values. The binary combinations with significant difference (NP), (NK) and PK (12.54, 13.20 and $14.05 \%$ ) respectively table 4.

Starch yield $\mathrm{Mg} \mathrm{h}^{-1}$ : appears from the table 4. The starch yield is the highest when treated with tri nano NPK (6.315 $\left.\mathrm{Mg} \mathrm{h}^{-1}\right)$ and lowest in comparison treatment $\left(4.872 \mathrm{Mgh}^{-1}\right)$ with significant difference. 
Table.4:Effect of fertigation Nano NPK fertilizers in yield and components of the yield of potato

\begin{tabular}{|c|c|c|c|c|c|c|}
\hline $\begin{array}{c}\text { Tr. } \\
\mathrm{N}^{\mathrm{O}}\end{array}$ & $\begin{array}{c}\text { Percentage of } \\
\text { Dry matter }\end{array}$ & $\begin{array}{c}\text { Tuber dry } \\
\text { Matter Yield } \\
\text { Mg ha }^{-1}\end{array}$ & $\begin{array}{c}\text { Percentage of } \\
\text { protein in } \\
\text { tuber }\end{array}$ & $\begin{array}{c}\text { Protein Yield } \\
\mathrm{kg} \mathrm{ha}^{-1}\end{array}$ & $\begin{array}{c}\text { Percentage of } \\
\text { Starch }\end{array}$ & $\begin{array}{c}\text { Starch Yield in } \\
\text { Tubers } \\
\text { Mg ha-1 }\end{array}$ \\
\hline $\mathrm{T}_{1}$ & $22.31 \mathrm{~b}$ & $6.843 \mathrm{c}$ & $10.00 \mathrm{a}$ & $684.020 \mathrm{~d}$ & $15.89 \mathrm{~b}$ & $4.872 \mathrm{~d}$ \\
\hline $\mathrm{T}_{2}$ & $19.13 \mathrm{e}$ & $8.120 \mathrm{~b}$ & $10.05 \mathrm{a}$ & $815.910 \mathrm{ab}$ & $13.06 \mathrm{e}$ & $5.542 \mathrm{c}$ \\
\hline $\mathrm{T}_{3}$ & $22.96 \mathrm{a}$ & $8.572 \mathrm{ab}$ & $9.20 \mathrm{~d}$ & $789.032 \mathrm{bc}$ & $16.47 \mathrm{a}$ & $6.147 \mathrm{ab}$ \\
\hline $\mathrm{T}_{4}$ & $22.11 \mathrm{~b}$ & $8.702 \mathrm{ab}$ & $9.05 \mathrm{e}$ & $787.528 \mathrm{bc}$ & $15.71 \mathrm{~b}$ & $6.183 \mathrm{ab}$ \\
\hline $\mathrm{T}_{5}$ & $18.55 \mathrm{f}$ & $8.656 \mathrm{ab}$ & $9.56 \mathrm{bc}$ & $827.776 \mathrm{a}$ & $12.54 \mathrm{f}$ & $5.851 \mathrm{abc}$ \\
\hline $\mathrm{T}_{6}$ & $19.29 \mathrm{e}$ & $8.616 \mathrm{ab}$ & $9.63 \mathrm{~b}$ & $829.253 \mathrm{a}$ & $13.2 \mathrm{e}$ & $5.895 \mathrm{abc}$ \\
\hline $\mathrm{T}_{7}$ & $20.25 \mathrm{~d}$ & $8.267 \mathrm{~b}$ & $9.48 \mathrm{c}$ & $783.970 \mathrm{c}$ & $14.05 \mathrm{~d}$ & $5.737 \mathrm{bc}$ \\
\hline $\mathrm{T} 8$ & $19.18 \mathrm{e}$ & $9.246 \mathrm{a}$ & $9.13 \mathrm{de}$ & $843.871 \mathrm{a}$ & $13.1 \mathrm{e}$ & $6.315 \mathrm{a}$ \\
\hline $\mathrm{T} 9$ & $21.28 \mathrm{c}$ & $8.300 \mathrm{~b}$ & $9.63 \mathrm{~b}$ & $798.866 \mathrm{bc}$ & $14.97 \mathrm{c}$ & $5.838 \mathrm{abc}$ \\
\hline
\end{tabular}

\section{Discussion}

The results of the current study in Table 3 and 4 show that there is a significan increase in growth parameters due to the role of nitrogen and available in the form of $\mathrm{NO}_{3}{ }^{-}$or $\mathrm{NH}_{4}{ }^{+}$which enhances plant growth and production significantly through the vital role in the biochemical and physiological functions of the plant (Jahan et .al.,2016). These results are consistent with what he has found (Rostami et. al., 2015). The presence of nitrogen in the available form leads to early growth, improves the quality of the yield, and increases protein content. promotes absorption of other nutrients including potassium and phosphorus and promotes total plant growth (Bloom, 2015; Hemerly, 2016). Potassium has a catalytic effect in the main step of protein synthesis. The production of proteins and enzymes that regulate all growth processes, i.e. $\mathrm{K}$ deficiency in the plant, may affect the synthesis of proteins despite the availability of available nitrogen $(\mathrm{N})$.

Potassium is responsible for its activation and synthesis (Patial, 2011). Phosphorus fertilization is a critical component of profitable potato production as many soils lack sufficient $\mathrm{P}$ to optimize crop growth. potato has a relatively high $\mathrm{P}$ requirement and is generally considered to be inefficient in taking up soil $\mathrm{P}$ (Woldgiorgis,2014). Phosphorus influences plant metabolism through its role in cellular energy transfer, respiration and photosynthesis (Soratto et. al., 2015). Phosphorus is also a structural component of phospholipids nucleic acids, coenzymes, and phosphor proteins and helps to store nutrients in seeds as phytic acid (Bundy et. al. 2005 Rosen and Bierman,2008). Therefore, an adequate supply of $\mathrm{P}$ is required by the plant from the earliest stages of growth to maturity (Vhuthu,2017).

Quasem and Abu-alruzk and Sahayatraj et. al., $(2009,2014)$ have menstioned. that nano fertilizers increase the availability of plant nutrients for a longer period and slow release with plant growth, which increases the composition of chlorophyll, photosynthesis, and dry matter production and, as a result, improves overall plant growth ( Al-Juthery et .al., 2018).The increase in the vegetative dry yield in the method of fertilizer additive with irrigation fertigation may be due to the role of best nutrition processing of nitrogen, phosphorus and potassium during addition with irrigation water.

The rate of photosynthesis, the production of more dry matter and yield productivity, and increases plant resistance to biotic and abiotic stress acompared with conventional fertilizers with dripping irrigation systems or spraying (Singh et. al., 2017, Khan et. al., 2017). The behavior of nanoparticles when entering the plant and binding to carriers proteinuria such as Aquaporin, Endocytosis and Ion channels. creating new openings and penetrating cell membranes or walls and thus stimulate the absorption of water and encourage the growth and production of plants (Schwab et.al., 2015).

These results are consistent with what has been achieved by (Abyaneh et. al., 2014). And the highest yield of fresh tubers. The increase rate is $38 \%$ with the use of nano nitrogen fertilizers. The biological yield distinguish of these results is due to the availability of the major nutrients NPK is working to create the balance of plant nutrition and regular (harmonious release with growth) in early stages of growth and thus improve metabolism and metabolic activity. 
This in turn leads to an increase in the various metabolic functions responsible for division and elongation in the cell and thus the increase in most vegetative growth indicators (Shafeek et. al., 2013, Kashif et al., 2014). These results are consistent with the results of (Janmohammadi et. al. 2016) when the potato crop is has been treated with two types of $\mathrm{N}, \mathrm{P}, \mathrm{K}$ fertilizers nano and conventional where the rate of biological yield $\left(40.22\right.$ and $\left.40.56 \mathrm{Mg} \mathrm{h}^{-1}\right)$ respectively. It is worth mentioning that the percentage of moisture in the tubers in general is $79.44 \%$, ie, the percentage of dry matter in the tubers is $20.56 \%$.

This percentage is very similar to what reached by has been (Hamadi and Al-Mishal, 1987) (80-72\%) and dry matter content in tubers reached is 23\%. In the same direction, (Al-Juthary, 2011 and Tilahun et. al., 2015). Nanomaterials are characterized by their slow release and high absorption efficiency, which is greater for the different metabolic reactions in the plant, which increases the rate of photosynthesis to the production of dry matter for vegetative and tubers (Qureshi et .al., 2018). What has been found by (Singh et al., 2017). in general, the protein content in the tubers ranged from 10.05 to $9.05 \%$.

This percentage is higher than that of (Al-Juthery, 2011) and (Al-juthery et al .,2018), which ranged between (7.8-9.2\%). This is what is the role of the nano fertilizer which works to improve the yield, quality of yield and increased protein content through optimal nutrient use (De Rosa et. al., 2010). The superiority of nano fertilizers is attributed to the traditional because it has a high surface area and a slow release that helps in the speed of absorption of nutrients, speed of penetration, representation and movement.

This leads to an increase in the speed of growth and increase the quality of protein and starch by activating and synthesizing the process of photosynthesis (Lal et. al., 2008) The protein content may be significantly affected by climatic conditions during vegetation, genetic traits and agricultural conditions" (Brzozwska, 2008, Wichrowska et .al., 2009). The percentage of starch in tubers in general reached $14.33 \%$.

This percentages is higher than those obtained by (Al-juthery et al., 2018) where the percentage of starch was 13.92\%. These results are consistent with they obtained (Janmohammadi et.al., 2016) When using $1 \mathrm{~kg} \mathrm{~h}^{-1} \mathrm{whole}$ nano-fertilizer, contain 11elements (N5\%, P 3\%, K 3\%, Fe 4.5\%, Zn 8\%, Ca 6\%, Mg 6\%, Mn 0.7\%, Cu 0.65\% $(0.65 \%)$ acompared to NPK $200 \mathrm{~kg} \mathrm{~h}^{-1}$ (20: 10: $5 \mathrm{NPK}$ ) for potato crop where the percentages of starch are $16.89 \%$ with $13.02 \%$ for nano and conventional fertilizers respectively. Starch yield is a characteristic quality of potato tubers in determining nutritional and industrial value.

Potato tubers are usually characterized by high dry matter content and starch as their main constituent (Wien, 1997). When nutrients are available continuously and along the period of growth, especially the major elements NPK as the low soil readiness leads to weaken vegetative growth and reduces the size of plants and thus reduces the efficiency of carbon representation, which affects the amount of materials manufactured and stored in the tubers (Pavlista and Blumenthal, 2000 and Delden, 2001).

\section{Conclusion:}

It can be concluded that good potato productivity can be achieved through the adoption of fertigation combined with nano N,P and K fertilizers and good irrigation management using dripping irrigation.

\section{References}

[1] A.O.A.C. 2000. Official method of analysis (17thed.). Gaithersburg, MD, USA: Association of Official Analytical Chemists, 967.21.

[2] Abyaneh,H.A;B, Maryam .2014. The effect of nanofertilizers on nitrate leaching and its distribution in soil profile with an emphasis on potato yield.nano science and nano technology.ISSN:0974-7494.

[3] Al Sahuki,M;and K,M Whaib.1990.Applications in the design and analysis of experiments.Baghdad university.Ministry of higher education and scientific research.

[4] Ali, N. S. and H. W. A. Al-Juthery.2017.The application of nanotechnology for micronutrient in agricultureal production (review article). The Iraqi Journal of Agricultural Sciences . (9) 48: 489-441.

[5] Al-juthery,H. W.A., N. S. Ali, D.Al-taee and E.A. H . M.Ali.2018. The impact of foliar application of nanoferilizer, seaweed and hypertonic on yield of potato.Plant Archevs.18(2): http://www.scimagojr.com.

[6] Al-juthery,H.W.A .2011.Effect of Different Fertilizers Sources and Rates and Irrigation Methods on Growth and Yield of Potato (Solanum tuberosum L.).

[7] Banjare, S; S. Gaurav; , S. K. Verma. 2014. Potato Crop Growth and Yield Response to Different Levels of Nitrogen under Chhattisgarh Plains Agro-climatic Zone, Indian Journal of Science and Technology, Vol. 7 pp. 1504-1508.

[8] Bloom, A.J., 2015. The increasing importance of distinguishing among plant nitrogen sources. Current opinion in plant biology, 25: 10-16. 
[9] Bres.W.2009. Estimation of nutrient losses from Open Fertigation Systems to Soil during Horticultural Plant Cultivation. Polish J. of Environ. Stud. Vol. 18, No. 3 (2009), 341-345.

[10] Brzozowska, I., 2008. Macroelements content in winter wheat grain as affected by cultivation and nitrogen application methods. Acta Agroph., 11: 23-32. (in Polish).

[11] Bundy, L.G., H. Tunney, and A.D. Halverson. 2005. Agronomic aspects of phosphorus management. In Phosphorus: Agriculture and the environment, ed. J.T. Sims and A.N. Sharpley, 685-727. Madison: American Society of Agronomy, Crop Science Society of America, Soil Science Society of Americ.

[12] De Rosa M.C; C. Monreal, M .Schnitzer; R .Walsh and Y. Sultan .2010. Nanotechnology in fertilizers. nat nanotechnol 5:91.

[13] Delden;A.V.2001.Yield and growth of potato and wheat under organic N management. Agronomy J.93:1370-1385

[14] FAO. 2013. FAO STAT Agriculture Database http://faostat.fao.org/DesktopDefault.spx.

[15] Fares,A and F. Abbas.2009. Irrigation Systems and Nutrient Sources for Fertigation. Soil and Crop Management.SCM-25.132.

[16] Hammadi FM and Al-Meshal AJ. 1987. Vegetable production, University of Baghdad, Iraq.

[17] Hemerly, A. 2016. Genetic controls of biomass increase in sugarcane by association with beneficial nitrogen-fixing bacteria', In Plant and Animal Genome XXIV Conference. Plant and Animal Genome, during month of January .

[18] Jahan,S.L;A.Niaz;M.Ghulam;H.AbdulHafeezlaghari;H.Khalid;A.tofique; A.Safdar; A.Ayaz.2016. Role of nitrogen for plant growth and development :areview advances in enviro mental Biology,10(9):209-218.

[19] Janmohammadi M., Pornour N., Javanmard A., Sabaghnia N. 2016. Effects of bio-organic, conventional and nanofertilizers on growth, yield and quality of potato in cold steppe. Bot. Lith. 22(2): 133-144.

[20] Kandil, A. A., A. N. Attia, , M. A.Badawi, A. E. Sharief, and, W. A. H. Abido.2011. Effect of Water Stress and Fertilization with Inorganic Nitrogen and organic Chicken manure on yield and yield components of potato. Australian Journal of Basic and Applied Sciences, 5 (9): 9971005.

[21] Karam, F., Y.Rouphacl, R. Lahoud, J.Breidi And G.Coll. 2009. Influence of Genotypes and potassium Application Rates on Yield and potassium Use Efficiency of Potato. J Agro; 8 (1): 27-32.

[22] Kashif, M.; K. Rizwan; M. Khan and A.Younis.2014 . Efficacy of macro and micro-nutrients as foliar application on growth and yield of ( Dahlia hybrida L. ) (Fresco) . IJCBS. 5:6-10.

[23] Khan, M. R., and T. F. Rizvi .2017. Application of Nanofertilizer and Nanopesticides for Improvements in Crop Production and Protection. In: M. Ghorbanpour et al. (Eds.), Nanoscience and Plant-Soil Systems, Soil Biology 48, , Springer International Publishing AG, DOI 10.1007/978-3-319-46835-8_15.

[24] Kilmer,V.J and L.T.Alexander.1949.Methods making mechanical analysis of soils.Soil Sci .68:15-24.

[25] Lal, R. 2008.Promise and limitations of soils to minimize climate change. J. Soil Water Conserv.63:113A-118A.

[26] Landon,L.R.1984.Tropical Soil Manual. Booker Agriculture international Limited .450 pp.

[27] Morales-Diaz ; H.O ,Ortega; A.M, Juárez.; G.P, Cadenas; S.M, González and A, Benavides- Mandoza.2017. Application of nanoelements in plant nutrition and its impact in ecosystems. vietnam academy of science and technology .

[28] Munour,O;Hussain.2011.Feasibility use of nanotechnology in the development of technology base arab industry. damascus university for economic and legal sciences .

[29] Naderi, M.R., and A. Danesh-Shahraki.2013. Nanofertilizers and their roles in sustainable agriculture. Int. J. Agric. Crop Sci. 5:2229-2232.

[30] Patil RB.2011. Role of potassium humate on growth and yield of soybean and black gram. International Journal of Pharma and Bio sciences 2(1) 242-246

[31] Pavlista, A.;D. and J.M. Blumenthal. 2000. Potatoes in nutrient management of agronomic crops . Publ. Univ Nebraska Cooperative extension (EC 155), Lincoln, NE

[32] Quasem J. M; A. S, Mazahreh. and K, Abu-alruz .2009. American J. Applied Sci. 6, 888896.

[33] Qureshi,A; D.K. Singh and S. Dwivedi.2018. Nano-fertilizers: a novel way for enhancing nutrientuse efficiency and crop productivity. Int.J.Curr. Microbiol .App. Sci. 7(2): 3325-3335.

[34] Rachna Rana ; Ramesh; K.Shilpa and G, Guleria.2014. Fertigation: a tool for efficient fertilizer and water management volume -2, Issue-1 (January-March).

[35] Rosen, C.J and P.M. Bierman. 2008. Potato (Solanum tuberosum L.) yield and tuber set as affected by phosphorus fertilization. American Journal of Potato Research 85: 110-120.

[36] Rostami , A.A;S, Morad;R, Zahra.2015. Effect of K nano-fertilizer and N bio-fertilizer on yield and yield components of tomato (Lycopersicon Esculentum L.) IJABBR- 2014- eISSN: 2322-4827 International journal of advanced biological and biomedical research journal homepage: www.ijabbr.com. 
[37] Safavi,F.G . 2016. Effect of nano potassium fertilizer on some parchment pumpkin(Cucurbita pepo) morphological and physiological characteristics under drought conditions .International Journal of Farming and Allied Sciences IJFAS Journal-367-371/ 30 June.

[38] Sahayaraj K; M ,Madasamy and. A, Anbu R .2014. J, Biopest 9 (1), 63-72.

[39] Sahayaraj K;Madasamy M. and Anbu R. A .2014. J, Biopest 9 (1), 63-72.

[40] Salim,S.Ch and N.Sh. Ali.2017.Guide For Chemical Analyses of Soil ,Water ,Plant and Fertilizers. University of Baghdad-College of Agriculture.pp:279.

[41] Schwab, F., G,Zhai; M, Kern., A, Turner.; J. L ,Schnoor; and M. R ,Wiesner, . 2015 . Barriers, pathways and processes for uptake, translocation and257-278.

[42] SCI. 2015. Statistical Yearbook of Iran. Statistical Center of Iran, Tehran, Iran.

[43] Segars, B. 2002. Efficient fertilizer use - fertigation. Section for fertilizers for injection into irrigation.

[44] Shafeek, M.; Nagwa, M.; Hassan, S. H and Nadia. 2013 .Effect of potassium fertilizer and foliar spraying with Etherel on plant development, yield and bulb quality of onion plants (Allium cepa L). J. Appl. Sci. Res., 9 (2): 1140 1146.

[45] Shedeed, S.I,S. M. Zaghloul and A. A. Yassen.2009. Effect of method and rate of fertilizer application under drip irrigation on yield and nutrient uptake by tomato. Ozean Journal of Applied Sciences. 2(2):139-147

[46] Singh,M.D., C. Gautam, O.P. Patidar,H.M Meena, G.Prakasha and Vishwajith. 2017. Nano-Fertilizers is a new way to increase nutrients use efficiency in crop production. international journal of agriculture. review article. International Journal of Agriculture Sciences. 9(7):3831-3833

[47] Soratto, RP, C. Pilon, A.M. Fernandes, L.A. Moreno. 2015. Phosphorus uptake, use efficiency, and response of potato cultivars to phosphorus levels. Potato Research 58: 121-134.

[48] Subramanian KS;C, Paulraj; S. Natarajan.2007. Plant nutrient management through nano fertilizers. in application of nanotechnology in agriculture,tamil nadu agricultural university, coimbatore, India

[49] Tilahun,A.G;D,Nigussie;T,Tamado.2015.Response of potato (Solanum tuberosum L.) yield and yield components to nitrogenfertilizer and plantin density at haramaya, eastern Ethiopia

[50] Vhuthu ,N.2017.Phosphorus fertilizer source and its effect on potato (Solanum tuberosum L.) production. MScThesis (Agronomy) at the Faculty of AgriSciences at Stellenbosch University.

[51] White, PJ; RE ,Wheatley; JP, Hammond; K ,hang .2007. Minerals, soils and roots. In: vreugdenhil D (ed) Potato biology and biotechnology, advances and perspectives. Elsevier, Amsterdam , pp 739-752.

[52] Wichrowska D; Wojdyła T.; Rogozińska I. 2009. Concentrations of some macroelements in potato tubers stored at $4^{\circ}$ i $8^{\circ} \mathrm{C}$. J Elementol., 14(2):373-382

[53] Wien; H.C. 1997. The Physiology of Vegetable Crops. CAB. International, New York, USA. .pp. 662

[54] Woldgiorgis,FG. 2014 Response of potato (Solanum tuberosum L.) to nitrogen and phosphorus application under irrigation in Dire Dawa, eastern Ethiopia. MSc ThesisHaramaya University. 